\title{
BOLZANO VERSUS KANT: MATHEMATICS AS A SCIENTIA UNIVERSALIS
}

\author{
PAOLA CANTÙ
}

\begin{abstract}
The paper will discuss some changes in Bolzano's definition of mathematics attested in several quotations from the Beyträge, Wissenschaftslehre and Grössenlehre: is mathematics a theory of forms or a theory of quantities? Several issues that are maintained throughout Bolzano's works will be distinguished from others that were accepted in the Beyträge and abandoned in the Grössenlehre. Changes will be interpreted as a consequence of the new logical theory of truth introduced in the Wissenschaftslehre, but also as a consequence ot the overcome of Kant's terminology, and of the radicalization of Bolzano's anti-Kantianism. It will be argued that Bolzano's evolution can be understood as a coherent move, if one compares the criticism expressed in the Beyträge on the notion of quantity with a different and larger notion of quantity that Bolzano developed already in 1816. This discussion is based on the discovery that two unknown texts mentioned by Bolzano can be identified with works by von Spaun and Vieth respectively. Bolzano's evolution will be interpreted as a radicalization of the criticism of the Kantian definition of mathematics and as an effect of Bolzano's unaltered interest in the Leibnizian notion of mathesis universalis. As a conclusion, it will be argued that Bolzano never abandoned his original idea of considering mathematics as a scientia universalis, i.e. as the science of quantities in general, and it will be suggested that the question of ideal elements in mathematics, which has been interpreted as a main reason for the development of a new logical theory, can also be considered as a main reason for developing a different definition of quantity.
\end{abstract}

\section{INTRODUCTION}

It is well known that Bolzano, after having criticized in the Beyträge the traditional definition of mathematics as a theory of quantities, ${ }^{1}$ and suggested an alternative characterization as a theory of forms, went back to the traditional definition

This paper was first presented at the International Conference Philosophy and Mathematics in the Work of Bernard Bolzano that took place in Prague on April 15-18, 2010. A section of the paper was developed and presented at the 9th National Conference of the Italian Society for Analytic Philosophy Truth, Knowledge, and Science held at the University of Padua on September 23-25, 2010. I thank the participants for their valuable remarks and comments.

${ }^{1}$ For a discussion of the origin and development of the so-called 'traditional' definition of mathematics, see Cantù [2003b, chap. 3]. 
in the Grössenlehre. This paper aims at understanding why Bolzano changed his mind, and what effect this change had on his conception of mathematics.

Firstly, I will claim that Bolzano's return to the definition of mathematics as a science of quantities was not a U-turn $(\S 2)$, because there are several essential issues that were maintained throughout all his writings. Bolzano was always convinced that mathematics cannot be restricted to the study of numbers and magnitudes ( $\S$ 2.1 ), because he never abandoned the idea that the definition of mathematics should not be based on a domain of objects: he always preferred other definitional criteria, such as a sharp distinction with respect to other forms of knowledge (philosophy, logic, other scientific disciplines), or methodological considerations. Bolzano did not renounce to the idea that mathematics is a truly conceptual science $(\S 2.2)$, nor did he change his mind concerning the fact that mathematical treatises include both analytic and synthetic propositions (§ 2.3).

Secondly, I will present some relevant changes that might support the claim that Bolzano's notion of mathematics did nonetheless undergo a significant evolution from 1810 to 1848, as already evident in the fact that he switched from the definition of mathematics as a theory of forms (Formenlehre) to a definition of mathematics as a theory of quantities (Grössenlehre) (§ 3.1). The development of the theory of ideas in themselves induced him to abandon the belief that mathematics should concern the conditions for the possibility of existence, because he remarked that mathematics could concern also ideas in themselves, which are not and cannot become actual (§ 3.3). In the Grössenlehre Bolzano considered any definition that could introduce a sharp distinction between mathematics and other sciences as unattainable $(\S 3.2)$. Besides, he gave a different evaluation of the role of analytic propositions in the Beyträge and in the Wissenschaftslehre, which might be partly explained as a result of a change in the understanding of the notion of analyticity $(\S 3.4)$. As a result, Bolzano became even more anti-Kantian than before (§ 3.5).

Thirdly, the apparent contradiction between the definitions suggested in the Beyträge and in the Grössenlehre will be explained on the basis of an enlargement of the notion of quantity (Größe) ${ }^{2}$ that Bolzano suggested already in 1816 (§ 4). The analysis will be based on the discovery that two unknown texts mentioned by Bolzano can be identified with works by von Spaun and Vieth respectively.

Finally, I will suggest two reasons why Bolzano altered certain features of his conception of mathematics and not others: his mathematical anti-Kantianism and

${ }^{2}$ In the following I will use the term 'quantity' to translate 'Größe', which corresponds to the Euclidean term 'méghezos'. 'Quantity' is thus distinguished from 'size' that corresponds to 'pelikotés' (see e.g. Klein [1934-36, p. 173]). I preferrred 'quantity' to 'magnitude', because the latter has acquired a very specific meaning in contemporary English, but also because Bolzano himself translates 'Grösse' with the latin term 'quantitas', as in Wolff, rather than with the term 'magnitudo' that was used in some Latin editions of Euclid's Elements. For a detailed analysis of the history of the terms, see Cantù [2003b, pp. 80-86]. 
the new logical theory developed in the Wissenschaftslehre. The changes mentioned in $\S 3$ will be explained as a side-effect of the theory of ideas in themselves, but also as a further move against Kant. The continuity elements discussed in $\S 2$ will be considered as reasons for defending the coherence of Bolzano's evolution and will be interpreted as aspects of his unaltered understanding of mathematics as a scientia universalis.

\section{Continuity: Four Never ABAndoned Features of mathematics}

2.1. Mathematical objects are not just quantities. In the first chapter of the Beyträge, Bolzano contrasted Euclid's lack of a definition of mathematics, and the traditional definition that can be found in contemporary textbooks:

It is well known that the oldest mathematical textbook, Euclid's Elements - which in some ways is still unsurpassed-contains no definition of the science with which it is concerned. Whether its immortal author did this out of a kind of willfulness, or because he thought it was not worthwhile, or because he did not know any valid definition to give us, I shall not venture to decide. By contrast, in all modern textbooks of mathematics this definition is put forward: 'mathematics is the science of quantity'. Kant has already found fault with this definition in his Kritik der reinen Vernunft (see the 2nd edition, p. 742) because in it, as he says, ' $n o$ essential characteristic of mathematics is stated, and the effect is also mistaken for the cause. ${ }^{3}$

Similar criticism of the traditional definition of mathematics was quite common among German-speaking philosophers: Kant, Hegel and after him Grassmann criticized the definition of mathematics as Grössenlehre. This is partly due to the fact that Wolff, introducing a German terminology for mathematics and philosophy in his Mathematisches Lexicon, had translated several distinct notions - moles, volumen, quantitas, magnitudo - by the same word: 'Größe'. ${ }^{4}$ Bolzano's rejection of the traditional definition begins by a mention of Kant's earlier critical remarks. This is something more than an argument ad auctoritatem. Bolzano agrees with Kant's objection: a satisfactory definition of mathematics should not be based on

${ }^{3}$ Cf. Beyträge $\S 1$, in Russ [2004, p. 91].

${ }^{4}$ For a detailed analysis of Wolff's contribution to the unification of the concept of magnitude and quantity in German terminology, see Cantù [2008]. The paper suggests that Wolff's terminological confusion, together with the heritage of the Latin translations by Euclid which had used the two terms magnitudo and quantitas to translate the Greek term "mégezos" might explain why so many German speaking philosophers and mathematicians questioned the meaning of the term Größe: e.g. Euler, Gauss, Kant, Hegel, Bolzano, Grassmann. 
its domain-i.e. quantities. While Kant argues that such a definition is inadequate because it mistakes the effect for the cause, and gives an explanation of why mathematics applies to quantities, Bolzano claims on the contrary that the definition is unsatisfactory because the domain of mathematics does not coincide with quantities; besides, the notion of quantity is not univocally determined.

Bolzano's criticism is expressed in $\S 2$ of the Beyträge, where he quotes an anonymous work Versuch, das Studium der Mathematik durch Erläuterung einiger Grundbegriffe und durch zweckmässigere Methoden zu erleichtern, published by Göbhardt in Mamberg und Würzburg 1805 (see Spaun [1805]). It is presumably a reprint of a book also published anonymously by Göbhardt in 1804 Versuch einer Begriffe der Mathematik zu erläutern und zu bestimmen. I suggest that the author, not identified until now, could well be Franz Ritter von Spaun, who after having worked for several years in the Austrian administration, was condamned for a writing that was considered politically dangerous, and from 1788 onwards, expecially during the ten years he passed in prison, devoted himself to mathematics. ${ }^{5}$ The text quoted by Bolzano contains a criticism of negative quantities, and was reviewed in the Jenaische Allgemeine Literatur-Zeitung by an anonymous reviewer "B.". ${ }^{6}$ The author, like Bolzano, argues that the objects of mathematics are neither quantities in the sense of conceivable entities, nor quantities in the sense of sensible objects. Bolzano quotes again the book in the Erste Begriffe der allgemeinen Größenlehre, where he repeats what he had already declared in the Beyträge, that is to say, that not every quantity need be real (i.e. wirklich) or wahrnehmbar, given that even space and time (to which quantities are often applied) are not real, nor can they be perceived. ${ }^{7}$ In both occasions Bolzano quotes the author's definition of quantity as something that exists and can be perceived by some sense.

Naturally everything here depends on what is understood by the word 'quantity'. The anonymous author of the book Versuch, das Studium der Mathematik durch Erläuterung einiger Grundbegriffe und durch zweckmässigere Methoden zu erleichtern. Bamberg and Würzburg, 1805 (S. 4), puts forward the following definition of

\footnotetext{
${ }^{5}$ Von Spaun wrote several other mathematical books, including Briefe über die erste Grundsätze der Mechanik (1807), Einleitung zur geometrischen Construction aller Probleme der sphärischen Trigonometrie (1811), Anleitung zur geradlinigen Trigonometrie (1818), Mein mathematisches Instrument (1825), but was also well-known for his radical criticism of Goethe's poetry.

${ }^{6} \mathrm{Cf}$. Anonymous [1807]. It would be interesting to verify whether the author could not be Bolzano himself.

7'Alles was ist und durch irgend einen Sinn wahrgenommen werden kann, ist eine Größe.' Ich wäre dagegen der Meinung, daß nicht jede Größe etwas Reales (wenn dieses soviel als etwas Wirkliches bedeuten soll) um so weniger etwas sinnlich Wahrnehmbares seyn müsse; ja ich glaube, daß nicht einmal Zeit und Raum (auf welche der Begriff der Größen doch ganz vornehmlich angewandt wird) etwas Wirkliches und sinnlich Wahnehmbares seyen." Erste Begriffe der allgemeinen Größenlehre, in Bolzano [1975, p. 224].
} 
quantity, 'A quantity is something that exists and can be perceived by some sense.' This definition is always one of two things, either too wide or too narrow, according to whether the author takes the words 'exists' and 'can be perceived' in their widest sense when they mean a purely ideal existence and a possibility of being thought, or in their narrower and proper sense in which they hold only for a sensible object which actually exists. In the first case, quantity would be every conceivable thing without exception and if we then defined mathematics as the science of quantity we would basically bring all sciences into the domain of this one science. On the other hand, in the second case, only sensible objects would be quantities, and the domain of mathematics would obviously then be excessively restricted-because immaterial things, e.g. spirits and spiritual forces, can also become an object of mathematics, and particularly of arithmetic. ${ }^{8}$

A deeper attention to other parts of the work of von Spaun shows that it aimed at solving mathematical controversies, for example the question of negative quantities, by means of a new definition of the concepts involved. Spaun claims that if quantities are things that can be perceived, one should then be able to perceive and determine distinctions between things, provided one has abstracted from all particularities: two things can then be distinguished either according to their succession [Reihe] or to their position [Lage]. The first is an algebraic approach, the latter a mathematical approach, because mathematics is a species of algebra (calculus): if one makes abstraction from position, then two things are still different according to their succession. ${ }^{9}$

Bolzano assumes the general notion of quantity, something that is composed of equal parts, or something that can be determined by means of numbers, ${ }^{10}$ and opposes it to a different notion of quantity (called here form), which amounts to something that is given, and that can be distinguished from other given things by means of position and/or succession, as it was suggested in the mentioned work by von Spaun. This means that mathematics cannot be restricted to the study of numerability. So, in some sense, the main reason why Bolzano refuses the traditional definition is because it is not applicable to all kinds of thing, as mathesis generalis should be, but rather introduces restrictive constraints.

Bolzano argues that the objects of mathematics are not "the objects to which the concept of quantity is especially applicable" either, because in that case all sciences,

${ }^{8}$ Beyträge, $\S 2$ in Russ [2004, p. 91.]

${ }^{9}$ Cf. Spaun [1805, pp. 4-5].

${ }^{10}$ Cf. Beyträge, § 3, in Bolzano [1974, p. 4]. 
logic included, would have to be considered as mathematical sciences; besides, no consideration of the frequency of application could ever provide a definite distinction between mathematical and non-mathematical sciences.

The concept of quantity is applicable to all objects, even to objects of thought. Therefore if one wanted to consider the mere applicability of the concept of quantity to an object a sufficient reason for counting the theory of that object among the mathematical disciplines, all sciences would in fact have to count as mathematics, e.g. even the science in which the proposition is proved that there are only four (or as Platner more correctly states, only two) syllogistic figures; or the science which states that there are no more and no less than four sets of three pure simple concepts of the understanding (categories), etc. Therefore in order to salvage this definition one would have to take into account the difference between rarer and more frequent applicability, i.e. count only those objects to be in mathematics to which the concept of quantity can be applied often and in many ways. But anyone can see that this would be an extremely vague, and not at all scientific, determination of the boundaries of the domain of mathematics. We must therefore look for a better definition. ${ }^{11}$

After having shown that several definitions of mathematics based on its domain of objects as quantities are inadequate, Bolzano turns to the analysis of Kant's suggestion, which is based on the opposition between philosophy and mathematics and on the notion of an a priori intuition that grants the possibility of a construction of mathematical concepts.

Bolzano's criticism of Kant will be further discussed in $\S 3.5$, but it must be noted here that the argument given by Bolzano to reject the definition of mathematics as a science of quantities is at the same time an argument against the Kantian definition. Rejecting the traditional definition because the effect is mistaken for the cause, Kant did not question the idea that mathematics concern only quantities. On the contrary, he intended to give an explanation of the reason why mathematics concern only quantities: quantities can be represented in space and time. So, the form of mathematical knowledge is the reason why it concerns only quantities. ${ }^{12}$

\footnotetext{
11" Beyträge, § 4 in Russ [2004, p. 92.]

12"Die philosophische Erkenntniß ist die Vernunfterkenntniß aus Begriffen, die mathematische aus der Construction der Begriffe. Einen Begriff aber construiren, heißt: die ihm correspondirende Anschauung a priori darstellen." Kant (1787) KrV. B742-3. "Alles, was im Raum und in der Zeit vorgestellt wird, hat extensive Größe." Kant (1821), Vorlesungen über die Metaphysik (Pölitz), p. 53. "Die Form der mathematischen Erkenntniß ist die Ursache, daß diese lediglich auf Quanta gehen kann." Kant (1787) KrV. B742-3. "Da die Größe den Gegenstand der Mathematik ausmacht, und in Betrachtung derselben nur darauf gesehen wird, wie vielmal etwas gesetzt sei, so
} 
In the Beyträge, on the contrary, Bolzano rejects the definition of mathematics as a science of quantities not only because the notion of quantity is too vaguely defined, but also because he believes that, no matter how broad the notion of quantity might be, mathematics would always concern objects that are definitely not quantities. Quantities are in fact considered as magnitudes (extensive or intensive) whose properties can be fully described by numbers. Neither the notion of geometrical point, nor the notion of a permutation can thus be included among quantities.

If we do not wish to move too far away from the use of language (something which we should surely never do even in the sciences without necessity), then we must understand by quantity, a whole in so far as it consists of several equal parts, or even more generally, something which can be determined by numbers. ${ }^{13}$

A similar argumentation is presented in the Grössenlehre, where Bolzano goes back to the traditional definition of mathematics (see $\S 3.1$ ). How is this possible? Firstly, Bolzano applies a principle that he had already enunciated in the Beyträge, and that constitutes a leitmotif of his work: the linguistic usage is relevant and should not be modified without necessity.

The traditional definition of mathematics that has been given up to now does not say anything else than that mathematics is the science of quantities (scientia quantorum). So I hope that my definition will not be blamed for differing too much from the ordinary one. ${ }^{14}$

Secondly, Bolzano is still convinced that a science cannot be univocally characterized by its domain of objects - and thus even if mathematics is defined as a science of quantities, this need not mean that it can be applied only to quantities.

However I have to explain that I did not keep the same expressions.

One should rightly say that mathematics is a theory of quantities,

leuchtet deutlich in die Augen, daß diese Erkenntniß auf wenigen und sehr klaren Grundlehren der allgemeinen Größenlehre (welches eigentlich die allgemeine Arithmetik ist) beruhen müsse." Kant (1864), Untersuchung über die Deutlichkeit der Grundsätze der natürlichen Theologie und der Moral, p. 282.

${ }^{13} \mathrm{Cf}$. also the following passage: "The concept of quantity, or of number, does not even appear in many problems of the theory of combinations (this very important part of general mathesis). For example, if the question is raised: which permutations - not how many-of the given things $a, b, c, . .+$ are admissible? In the particular parts of mathematics, chronometry, geometry etc., as the names suggest, some object other than the concept of quantity (e.g. time, space, etc.) appears everywhere, and the concept of quantity is just frequently applied to it. So that in all these disciplines there are several axioms and theorems which do not even contain the concept of quantity. Thus, for example, in chronometry the proposition that all moments are similar to each other, and in geometry that all points are similar to each other, must be established. Such propositions, which do not contain the concept of a quantity or number at all, could never be established in mathematics if it were merely a science of quantity." Cf. Beyträge, I, $\S 3$ in Russ [2004, p. 92].

${ }^{14}$ Grössenlehre, Einleitung, § 2, Anm. in Bolzano [1975, p. 27]. 
only if the objects that are considered in the different mathematical sciences are quantities altogether and just because of the fact that they are considered in those sciences. But that is not the case. On the contrary, many mathematical sciences rather concern, at least partially, objects that are not quantities, even if the concepts of quantity and number are used to examine them. ${ }^{15}$

Thirdly, he assumes a different, and more general meaning of the word quantity, as we will see in $\S 4$. So, Bolzano reverts to the traditional definition of mathematics because he wants to preserve a well-established, almost idiomatic expression, but at the same time he changes its meaning by giving a different explanation of the concept of quantity. The linguistic use, and the mathematical practice are maintained but the usual way of speaking is combined with a conceptual change. Besides, the reference to quantities that is suggested in the definition can be understood on pragmatic grounds: it is useful to underline the propaedeutic function of the general theory of quantities in mathematics.

So far, the evolution from the definition of mathematics as a theory of forms to the traditional definition of mathematics as a science of quantities did not appear as a radical change, but we will see in $\S 3$ what further changes induced Bolzano to abandon the definition of mathematics as a theory of forms.

2.2. Mathematics without intuitions: a truly conceptual science. A constant feature of Bolzano's anti-Kantianism is the refusal to grant intuitions any role in mathematics: the latter is a merely conceptual science. In the Appendix to Beyträge, where Bolzano makes his critique to Kant, concepts and intuitions are defined as following: "All ideas are either intuitions, i.e. ideas of an individual, or concepts, i.e. ideas of something general."16 Against Kant, Bolzano argues that there is no such a thing as pure intuition: space and time are forms, but they are concepts, just like smell and colour. He also argues that arithmetic does not require the pure intuition of time in order to be universal and necessary knowledge, nor does geometry require the pure intuition of space. Mathematics is a conceptual science, that is to say, a science that contains just concepts. A non conceptual judgment is on the contrary a judgment that contains at least an intuition. Mathematics does not contain any intuition. Its objects are not individual but general.

The harsh criticism of Kant's notion of an a priori intuition is due to Bolzano's strong belief that mathematics is a conceptual science. In the Beyträge he explicitly defines it as a "a science which deals with the general laws (forms) to which things must conform [sich richten nach] in their existence [Dasein]", and adds that

${ }^{15}$ Grössenlehre, Einleitung, § 2, Anm. in Bolzano [1975, p. 27].

${ }^{16}$ Beyträge, Appendix, $\S 2$, in Russ [2004, p. 132.] 
"mathematics never deals with a single thing as an individual but always with whole genera [Gattungen]."17 Having assumed the Kantian distinction between intuitions as ideas of an individual and concepts as ideas of something general, there is no doubt that mathematics, concerning only genera, is a conceptual science.

Bolzano wants to eliminate any appeal to intuition from mathematics. As a mathematician he has to solve the problem of imaginary or ideal quantities, that is to say, concepts that do not have a corresponding intuition in mathematics (the infinite line, complicated spatial objects in stereometry, etc...). Bolzano does not question their possibility, but grounds it on the independence from intuition and imagination.

The proposition that every straight line can be extended to infinity has no intuition behind it: the lines which our imagination can picture are not infinitely long. In stereometry we are often concerned with such complicated spatial objects, that even the most lively imagination is no longer able to imagine them clearly; but we none the less continue to calculate with our concepts and find truth. ${ }^{18}$

2.3. Mathematics contains analytic and synthetic propositions. In the Beyträge Bolzano maintained the traditional Kantian definition of analyticity, and he claimed that mathematics contains synthetic propositions (e.g. axioms) and analytic propositions, which play the role of definitions. In the Wissenschaftslehre Bolzano introduced a different definition of analyticity, but mathematics still contains both analytic and synthetic propositions. Only their role is antithetic to the role they played in Kant's theory.

The distinction between analytic and synthetic judgments is introduced in the Beyträge with respect to judgments of the form $<S$ is a kind of $P>$, which means that $S$ is a species of the genus $P$. If I can find a differentia specifica $D$ so that $S$ is decomposable into $P$ cum $D$, then the judgment is analytic: $<P$ cum $D$ is a kind of $P>$. If I cannot find $D$, then I can only decompose $S$ into $P$ cum $S$, which is but an apparent definition, and $S$ is a simple concept. Bolzano mentions the following examples: a) "A point is a spatial object" is a synthetic judgment, because it can only be decomposed into "A spatial object which is a point is a spatial object"; b) "Human are animals" on the contrary is analytic, because it can be decomposed into: "An animal who is rational is an animal".

A classification of judgements quite different from those considered so far, which has, since Kant, become particularly important, is

${ }^{17}$ Beyträge, § 8, in Russ [2004, p. 94.]

${ }^{18}$ Beyträge, Appendix, § 9, in Russ [2004, p. 136.] 
the classification into analytic and synthetic judgements. In our socalled necessity judgements, the subject appears as a species whose genus is the predicate. But this relation of species to genus can be of two kinds: either there is a characteristic which can be thought of and stated in itself, which is added in thought as a differentia specifica to the genus (predicate $\mathrm{P}$ ) to produce the species (subject $\mathrm{S}$ ) or not. In the first case the judgement is called analytic; in every other case, which may be any of the classes mentioned in $\S 15$, it is called synthetic. ${ }^{19}$

The Kantian distinction between analytic and synthetic judgments is thus maintained: a judgment is called analytic if the predicate is contained directly, or indirectly, in the definition of the subject; every other judgment is synthetic. ${ }^{20}$ Provided that one does not consider synthetic judgments as based on any intuition, then one might agree with Kant that the majority of propositions of arithmetic are synthetic.

The principle of sufficient reason, and the majority of propositions of arithmetic are, according to Kant's correct observation, synthetic propositions. $^{21}$

A new definition of analytic and synthetic propositions is presented by Bolzano in the Wissenschaftslehre (especially $\S 148$ ), where it is grounded on a new theory of truth. Bolzano distinguishes between analyticity and logical analyticity: both are associated to a proposition in itself, the objective counterpart of a sentence or of a judgment. Each proposition in itself has a degree of validity (Gültigkeit) with respect to some of its parts (representations in itself) that might be considered as variables. The degree of validity of a proposition with respect to one or more of its parts is expressed by the ratio of the number of true propositions and the number of all (objectual) propositions that are obtained by variation of that part or those parts of the proposition. A proposition is universally valid or invalid with respect to those parts when the ratio is 1 or 0 respectively. A proposition is analytic if it is universally valid or invalid with respect to at least one of its variable parts. A proposition is logically analytic if it is universally valid or invalid with respect to all its non logical parts. A proposition is synthetic if it is not analytic. Mathematical truths are partly analytic, partly synthetic.

But suppose there is just a single [auch nur ein einziger] idea in it [in a proposition] which can be arbitrarily varied without disturbing its

$1{ }^{19}$ Beyträge, II $\S 17$ in Russ [2004, p. 115.]

20"In other words an analytic judgement is such that the predicate is contained directly, or indirectly, in the definition of the subject, and every other one is synthetic." Beyträge, II $\S 17$ in Russ [2004, p. 115.]

${ }^{21}$ Beyträge, Appendix $\S 8$ in Russ [2004, p. 135.] 
truth or falsity, i.e. if all the propositions produced by substituting for this idea any other idea we pleased are either true altogether or false altogether [...] I permit myself, then, to call propositions of this kind, borrowing an expression from Kant, analytic. All the rest, however, i.e. in which there is not a single idea that can be arbitrarily varied without affecting their truth or falsity, I call synthetic propositions. ${ }^{22}$

To conclude, Bolzano does not change his mind concerning the fact that mathematical treatises include both analytic and synthetic propositions, even if, as we will see in $\S 3.4$, the role of such propositions might vary according to a variation of their respective definitions. Nor does he renounce the idea that mathematics is a truly conceptual science, or that its domain includes other objects besides quantities.

\section{Relevant changes Between Beyträge and Grössenlehre}

3.1. Changing the definition of mathematics. A first undeniable difference between the Beyträge and the Grössenlehre concerns the definition of mathematics itself. In the Beyträge Bolzano criticized, as we have already mentioned in $\S 2.1$, the traditional definition of mathematics as a theory of quantities, and suggested an alternative characterization as a theory of forms.

I therefore think that mathematics should best be defined as a science which deals with the general laws (forms) to which things must conform in their existence. By the word 'things' I understand here not merely those which possess an objective existence independent of our consciousness, but also those which simply exist in our imagination, either as individuals (i.e. intuitions) or simply as general concepts, in other words, everything which can in general be an object of our capacity for representation. Furthermore if I say that mathematics deals with the laws to which these things conform in their existence, this indicates that our science is concerned not with the proofs of the existence of these things but only with the condition of their possibility. ${ }^{23}$

Some years later, in the unfinished work Grössenlehre he turned back to the traditional definition:

When one defines Mathematics as a science of quantities, and I basically turned back to such a definition, one undoubtedly assumes

${ }^{22}$ Wissenschaftslehre, $\S 148$ in Bolzano [1837, vol. 1, p. 83]. For the criticism of Kant see also $\S$ 315 in Bolzano [1837, vol. 3, p. 246 ss.].

${ }^{23}$ Cf. Beyträge, I, § 8, Russ [2004, p. 94]) 
the word quantity in a broader meaning, because one certainly considers the Theory of numbers as a mathematical discipline, and as one of the most important disciplines. ${ }^{24}$

\subsection{Abandoning the sharp distinction between mathematics and other} sciences. In the Grössenlehre the sharp distinction between mathematics and other sciences that Bolzano had defended in the Beyträge is considered as unattainable, or at least as incompatible with the usual linguistic practice of mathematicians. And the latter 'mathematical need' has now become more important than the 'philosophical' need for a foundation of science that might account for a sharp disciplinary distinction.

"[...] a science deserves to be called mathematics if a considerable part of its theory contains determinations of quantity whose correctness might be understood only on the basis of considerations on the nature of magnitudes, considerations that require a proper introduction. This addition will probably appear to many as objectionable, and so it appeared to me - I make no secret of it since it reduces the difference between mathematical sciences and non mathematical sciences to a 'more or less' question. I do not deny this might be a mischief, but I do not see how one could avoid it, without determining the concept of mathematics in a way that differs radically from the dominant linguistic use and that will originate more confusion than advantages. [...] Anyway, this seems to me to have been the rule followed by mathematicians, as they increased the number of the mathematical sciences $[\ldots]^{25}$

This change is related to the overcome of the interest in foundational questions such as demarcation, and in particular to the overcome of the urgency to give a definition that is specular to the one given by Kant (see further $\S 3.5$ ). By the way, it is to be noted that these criteria are not only typical features of the Kantian conception of mathematics, but also necessary conditions for a satisfactory definition of a scientific discipline according to the standards that became widespread after the flourishing of encyclopedias in the 18th century: a science is defined by its position in the tree of knowledge. Besides, the opposition to philosophy was a standard way to account for the difference in certainty, rigor and intersubjective agreement between the two disciplines in the "geometric century". ${ }^{26}$

${ }^{24}$ Grössenlehre, Einleitung, $\S 1$ in Bolzano [1975, p. 25].

${ }^{25}$ Grössenlehre, Einleitung, §2, Anmerkung in Bolzano [1975, p. 29].

${ }^{26}$ For a characterization of the era between Spinoza and Kant as a "geometric century" see Basso [2004]. 


\subsection{Mathematics does not concern the conditions of possibility of objects} that might come to existence. The definition of mathematics as a theory of forms explained the opposition between philosophy and mathematics:

the former concerns itself with the question, how must things be made in order that they should be possible? The latter raises the question, which things are real-and indeed (because it is to be answered a priori) — necessarily real? Or still more briefly, mathematics would deal with hypothetical necessity, metaphysics with absolute necessity. ${ }^{27}$

Nonetheless the definition implied that mathematics, dealing with the conditions of possibility of things, applies only to things that might become actual. This definition of mathematics and philosophy is abandoned in the Grössenlehre because the foundational problem of demarcation has become less urgent, since Bolzano is more interested in giving an appropriate role to logic rather than in giving a symmetric and opposite definition of philosophy and mathematics. But it is also abandoned because Bolzano has developed, in the meantime, his logical theory of ideas in themselves in the Wissenschaftslehre. If mathematics has to maintain the same generality that it had in the Beyträge, it should apply to all things, and thus to ideas in themselves too, which are not and cannot become actual.

In the Beyträge mathematics is a hypothetical science: it concerns the conditions of the possible existence of objects - not only real objects, but also objects that exist only in the imagination.

I therefore think that mathematics should best be defined as a science which deals with the general laws (forms) to which things must conform in their existence. By the word 'things' I understand here not merely those which possess an objective existence independent of our consciousness, but also those which simply exist in our imagination, either as individuals (i.e. intuitions) or simply as general concepts, in other words, everything which can in general be an object of our capacity for representation. Furthermore if I say that mathematics deals with the laws to which these things conform in their existence, this indicates that our science is concerned not with the proofs of the existence of these things but only with the condition of their possibility. ${ }^{28}$

${ }^{27}$ Beyträge, I. $\S 9$, in Russ [2004, pp. 94-95.]

${ }^{28}$ Cf. Beyträge, I, § 8, in Russ [2004, p. 94.] 
But from the Wissenschaftslehre onwards Bolzano developed a new theory of ideas and propositions in themselves, and mathematics should concern such entities as well. Bolzano explicitly admits that he has changed his mind.

More than thirty years ago I believed I could trace a more precise boundary between mathematics and the other sciences, as I attributed to mathematics all those truths that do not concern the real existence (Daseyn) but only the conditions for the possibility of existence. But I abandoned this thought as soon as I realized that mathematical theories do not refer only to things that are real or that might become real (i.e. to things that are possible). ${ }^{29}$

The change might appear less radical, if one takes into account a possible variation in the notion of possibility itself, which could amount to mere conceivability in the Beyträge and to the possibility to become actual in the Grössenlehre. ${ }^{30}$

3.4. The different role played by analytic and synthetic judgements. As already mentioned in $\S 2.3$, the different definition of analyticity adopted in the Wissenschaftslehre implies a different evaluation of the role of analytic and synthetic judgements in scientific works, which in turn implies a further move against Kant.

The distinction between analytic and synthetic judgments is relevant to understand their respective roles in mathematics. In the Beyträge analytic judgments cannot be considered as axioms, for they are composite and thus provable. They are actually linguistic propositions rather than judgments, because they inform us on different designations used to denote the objects rather than on the objects themselves. Like Kant, Bolzano considers them as not ampliative, and therefore as not properly deserving a place in a scientific system.

From this definition it now follows immediately that analytic judgements can never be considered as axioms, indeed, in my opinion they do not even deserve the name of judgements, but only that of propositions, they teach us something new only as propositions, i.e. insofar as they are expressed in words, but not as judgements. In other words the new [fact] which one can learn from them never concerns concepts and things in themselves but at most only their designations. Therefore, they do not even deserve a place in a scientific system, and if they are used, it is only to recall the concept designated by a certain word, just as with conventions. In any case,

\footnotetext{
${ }^{29}$ Grössenlehre, Einleitung, § 2, Anmerkung in Bolzano [1975, p. 30].

${ }^{30}$ I thank Wolfgang Künne for this remark.
} 
it is decided even according to the usual view, that analytic judgements are not axioms, for their truth is not recognized from them themselves, but from the definition of the subject. ${ }^{31}$

Synthetic judgments are axioms for two reasons. On the one hand, because "there are true definitions only for concepts which are composite, and therefore also decomposable again," ${ }^{\prime 2}$ that is to say only analytic propositions might play the role of definitions. On the other hand, because axioms have to be unprovable and all analytic propositions are provable. ${ }^{33}$ So, after having proved that there are some synthetic judgments (e.g. judgments whose subject is a simple concept), ${ }^{34}$ Bolzano argues that mathematics has axioms, because there are simple concepts that belong properly to mathematics.

If the foregoing is correct, the question can now be answered, 'whether mathematics also has axioms?'. Of course, if all mathematical concepts were definable concepts, then there could be no axioms in the mathematical discipline. But since there are simple concepts which belong properly to mathematics ( $\S 8)$, one certainly has to acknowledge actual axioms in it. The domain of the axioms stretches as far as that of the purely simple concepts: where the latter end and the definitions begin, there also the axioms come to an end and the theorems begin. ${ }^{35}$

As a consequence of the different definition of analyticity given in the Wissenschaftslehre (see $\S 2.3$ ), mathematics still contains both analytic and synthetic truths, but their role is quite different.

There are universal formulations of mathematical truths that are synthetic but if one instantiates them, one obtains an analytic truth. For example, "The angles of this triangle are together equal to two right angles" is analytic with respect to 'this'. Similarly, "The angles of an equilateral triangle are together equal to two right angles" is analytic with respect to 'equilateral'. On the contrary, "The angles of

${ }^{31}$ Beyträge, II $\S 18$ in Russ [2004, p. 115.]

32 Beyträge, II $\S 18$ in Russ [2004, p. 104.]

33"I believe I have found out that all judgements whose subject or predicate are composite concepts must be provable judgements." Beyträge, II $\S 16$ in Russ [2004, p. 114.] "Hence it now follows that the really unprovable propositions, or axioms, are only to be sought in the class of those judgements in which both subject and predicate are completely simple concepts." Beyträge, II $\S$ 20 in Russ [2004, p. 117.] "If therefore the word 'axiom' is to be taken in an objective sense we must understand by it a truth which we not only do not know how to prove but which is in itself unprovable." Beyträge, II $\S 11$ in Russ [2004, p. 110.]

34"Therefore if all our judgements were analytic there could also be no unprovable judgements, i.e. axioms at all. [...] we want to try and demonstrate, in a way independent of $\S 15$, that there actually are synthetic judgements. All judgements whose subject is a simple concept are thereby already synthetic." Beyträge, II $\S 19$ in Russ [2004, p. 116.]

${ }^{35}$ Beyträge, II $\S 22$ in Russ [2004, p. 119.] 
any triangle are together equal to two right angles" is synthetic, and the previously mentioned truths are provable from this truth. ${ }^{36}$ This example looks paradoxical: a universal proposition is considered to be synthetic, whereas if one instantiates it, one obtains an analytic proposition. De Jong [1997] has suggested an interesting interpretation: a Kantian example of a synthetic a priori proposition that was considered to be grounded on intuition is transformed into an analytic proposition. Bolzano's criticism of Kant's recourse to intuitions is here more radical, and it explains why analytic truths deserve a place in a scientific system: given the fact that they are not self-evident, some of them deserve not only a place but also a proof in the system, e.g. a derivation from a general synthetic principle.

From these examples one can already derive that not every analytic proposition expresses a self-evident truth, and thus the aim of teaching analytic propositions to somebody is not fully superfluous; on the contrary it's quite clear that even pure analytic propositions are sometimes so remarkable that they not only deserve a place in a textbook, but they make us feel obliged to guarantee their truth with a proof. And indeed it cannot be denied that such analytic propositions, whose truth is not directly evident, can easily be known as true, after one has learned a synthetic truth from which they follow. ${ }^{37}$

3.5. A progressive distantiation from Kant. It is well known that the Kantian definition of mathematics as the "knowledge gained by reason from the construction of concepts" has been extremely influential in the early 19th century, and that Bolzano was among its harsher critics. As a matter of fact, Bolzano's criticism of Kant is one of the most coherent features of his epistemology: if the Betrachtungen apparently accept several Kantian remarks on geometry, from the Beyträge onwards Bolzano never stops criticizing Kant's notion of a priori intuition, Kant's claim that mathematics contains propositions based on an a priori intuition of space and time, and the kind of distinction he introduces between philosophy and mathematics. These issues, briefly mentioned in the Beyträge ( $\S 9)$, in the Grössenlehre and in the Paradoxes of the Infinite - where Kant's "idea of space as a (subjective) form of intuition" is referred to as an unfortunate idea ${ }^{38}$ —are extensively discussed in the Appendix to the Beyträge, ${ }^{39}$ in the Wissenschaftslehre, in Athanasia, and of course

${ }^{36}$ Cf. Wissenschaftslehre, $\S 197$ in Bolzano [1837, vol. 2, p. 333 ss.].

${ }^{37}$ Wissenschaftslehre, $\S 447$ in Bolzano [1837, vol. 4, p. 116].

38 "until finally Kant got the unfortunate idea, still repeated by many today, of considering space as well as time not to be something objective, but to be a mere (subjective) form of our intuition." Cf. Russ [2004, p. 646.]

39"The critical philosophy seems to promise us one [a better definition] [...] mathematics is a science of the construction of concepts (A712). [...] For my part I wish to admit openly that I have 
in Prihonsky's Neuer Anti-Kant. ${ }^{40}$ But Bolzano's anti-Kantianism underwent a significant evolution.

In the Beyträge the need to criticize Kant dictates Bolzano's agenda. His main aim is apparently that of deconstructing Kant's definition point by point. Where Kant speaks of intuition, Bolzano speaks of pure concepts; where Kant speaks of quantities, Bolzano speaks of forms; if Kant ignores logic, Bolzano develops it in details as part of an analysis of the notion of a mathematical proof. Besides, Bolzano's terminology is Kantian, because Bolzano adopts Kant's definition of intuition, concept, analytic, synthetic, etc. Thirdly, Bolzano himself makes a connection between the need of a new definition and Kant's criticism quoting the review of a work by Vieth (cf. § 4). ${ }^{41}$ Finally, like Kant, Bolzano's characterization of mathematics is developed by opposition to philosophy, and in order to explain why mathematics applies to a certain domain of objects, and thus how it can be sharply distinguished from other sciences.

From the Wissenschaftslehre onwards a new logical theory and new definitions of the main concepts are introduced. I claim that this corresponds to a radicalization of the opposition to Kant, or at least to a form of opposition that is no more internal but rather external to the Kantian framework, because the return to the traditional definition of mathematics as a science of quantities was the only further anti-Kantian assumption that Bolzano could make.

To summarize, the changes in the conception of mathematics are due to changes in Bolzano's logic: the new theory of truth involves a different definition of analytic and synthetic judgments, and the introduction of ideas in themselves involves a different conception of mathematical entities. But they can also be related to a gradual overcome of Kant's terminology (e.g the definition of analyticity, but also the renouncement to define mathematics by opposition to philosophy), and to a radicalization of Bolzano's anti-Kantianism (e.g. the different interpretation of the role of analytic and synthetic truths in mathematics, but also the return to the traditional definition that Kant had explicitly criticized).

not yet been able to convince myself of the truth of many doctrines in the critical philosophy, and especially of the correctness of the Kantian claims about pure intuitions and about the construction of concepts using them. I still believe that in the concept of a pure (i.e. a priori) intuition there already lies an intrinsic contradiction. Much less can I persuade myself that the concept of number must necessarily be constructed in time and that consequently the intuition of time belongs essentially to arithmetic." Beyträge, Appendix, $\S \S 5-6$ in Russ [2004, p. 93.]

${ }^{40}$ Concerning the distinction between philosophy and mathematics see in particular pp. 216-17, repr. in Prihonsky [2003, pp. 172-173].

${ }^{41}$ Beyträge, I, § 7, in Russ [2004, p. 93]. 


\section{ENLARGING THE NOTION OF QUANTITY}

It is well known that in the Beyträge Bolzano criticizes the definition of mathematics as a science of quantities saying that no matter how one defines quantities, the domain of mathematics will never correspond exactly to the domain of quantities. More generally, one could say that however one defines a class of objects, the domain of mathematics will never coincide exactly with it. So, better define mathematics as a science of forms rather than as a science of those objects which are called quantities.

Another interesting quotation in $\S 7$ of the Beyträge, whose author is here identified for the first time, ${ }^{42}$ comes from a review of Anfangsgründe der Mathematik by Gerhard Ulrich Vieth [1805] published in the Neue Leipziger Literaturzeitung. ${ }^{43}$ In the review Leibniz is explicitly mentioned, and quantity is defined "as the object of mathematics only because it is the most general finite form", so that mathematics is by nature a general theory of forms. Bolzano remarks that he has

included in the first books of his Miscellanea Mixta, just before

he started his Miscellanea Mathematica, some reviews and even mathematical texts. Here is a list of them. [....] In Notebook III (towards the end) Vieth's Anfangsgründe der Mathematik. ${ }^{44}$

Vieth's book is quoted several times by Bolzano, for example in Miscellanea mathematica (1814), ${ }^{45}$ where it is analyzed in details, or in Erste Begriffe der allegemeinen Grössenlehre (1816), ${ }^{46}$ where Bolzano discusses Vieth's concept of a negative quantity, which is defined as a quantity that decreases some other quantity, or again in the Grössenlehre. On the notion of quantity Bolzano declares that Vieth shares the same conception as Kästner, i.e. that quantity is something that increases [vermehren] and decreases [vermindern]. ${ }^{47}$

\footnotetext{
${ }^{42}$ For further details see Cantù [forthcoming].

${ }^{43}$ Bolzano actually quotes the right number of the review, but mentions the name of the previous series: Leipziger Literaturzeitung. The quotation can be found in Neue Leipziger Literaturzeitung, July 1808, section 81, pp. 1288-1294 Cf. Anonymous [1808].

44"In den Miscellaneis mixtins, in den ersteren Heften habe ich, bevor ich noch einige Hefte wie diese für Mathematik hatte, Recensionen, auch mathematische Schriften eingetragen. Hier folgt ein Verzeichniss derselben. [...] Im Heft III (gegen Ende) Vieths Anfangsgründe der Mathematik)" Bolzano [2000, p. 146].

${ }^{45}$ Bolzano [1990, pp. $\left.106 \mathrm{ff}.\right]$.

${ }^{46}$ Bolzano [1977, p. 276].

${ }^{47}$ As a traditional definition he mentions the one by Hausen, Kästner, Horvath, Vieth, Voigt, Rothe, Kraushaar, Crelle, ecc. As already mentioned in $\S 2.1$, the definition goes back to Wolff.
} 
In the review mentioned by Bolzano in the Beyträge, the author criticizes the Kantian definition of mathematics, and expecially the idea that mathematics concerns only quantities that can be represented in space and time. ${ }^{48}$ Against the traditional definition of quantity as something that increases or decreases the reviewer introduces a more general notion of quantity as the most general form of finitude. ${ }^{49}$

It should be noted that when Bolzano goes back to the definition of mathematics several years later, something has changed in between. On the one hand he has introduced a different definition of quantity, which can be found already in the Miscellanea Mathematica. Quantity is a

species of things, between any two of those we can assert one and just one of the following reciprocal relations: either they are equal one to the other or one contains a part that is equal to the other..$^{50}$

This notion of quantity makes no reference to decomponibility in equal parts or to measurability, as Bolzano himself explains in Über den Begriff der Größe und die verschiedenen Arten derselben (1816). After having introduced the concepts of number [Zahl], relation [Verhältniss], and set [Menge], Bolzano presents the following definition of quantity [Größe]:

Each quality of an object has a quantity, if this quality can be considered as a set of parts in such a way that for any two things one of them contains something that is equal to the other, that is to say, these two things either are equal or in one of them there is as a part something that is equal to the other. And this property itself is called the quantity (quantitas) of the thing. ${ }^{51}$

\footnotetext{
48“Aber die Mathematik bezieht sich weder allein auf Dinge, die sich in Zeit und Raum darstellen lassen, noch auch werden die Dinge, die sich in Zeit und Raum darstellen lassen, in der Matheamtilk allein in so fern betrachtet, als sie Grössen sind, weil sie acuh der Gestalt und Art nach construirt werden; z.B. + und -, commensurabel und incommensurabel, gerade und krumm, gleichförmig und ungleichförmig, stetig und discret, sind doch wohl mathematische Begrtiffe? Dennoch aber haben sie mit Grösse nichts zu thun." Anonymous [1808, p. 1291].

49"Die Grösse ist nur darum Gegenstand der Mathematik, weil sie die allgemeinste Form ist, endlich zu seyn, die Mathematik aber ihrer Natur nach eine allgemeine Formenlehre ist; und zwar Arithmetik insofern sie die Grösse als die allgemeine Form endlicher Dinge, Goemetrie, insofern sie den Raum als die allgemeine Form der Natur, Zeitlehre, insofern sie die allgemeine Form der Kräfte, Bewegungslehre, insofern sie die allgemeine Form der im Raume wirkenden Kräfte betrachtet, und alle diese Formen in ihren innern, weitern Beschränkungen, ausbildet." Anonymous [1808, p. 1291].

${ }^{50}$ Grössenlehre, Einleitung, § 1, in Bolzano [1975, pp. 25-6].

51"Jede Beschaffenheit einer Sache hat eine Größe, wenn sich diese Beschaffenheit betrachten läßt als eine Menge von Theilen der Art, daß von je zweyen der eine allemahl in dem andern gleichkommendes Ding in sich faßt, d.h. daß diese zwey Theile entweder einander gleich kommen, oder daß in dem einen ein dem andern gleich kommendes Ding als Theil vohanden ist. Und diese Eigenschaft selbst heißt man die Großheit (quantitas) des Dinges." Über den Begriff der Größe und die verschiedenen Arten derselben, § 9, in Bolzano [1977, p. 195].
} 
Bolzano distinguishes between decomponibility in equal parts (which is not necessary) and the condition of being equal or unequal with respect to some other quantity (which is necessary). And the latter condition does not yet amount to measurability. Bolzano also clarifies that not all quantities are measurable, but just those for which one can determine a measure unit and a rule to determine how many equal parts of the measure unit are contained in the given quantity. ${ }^{52}$

In the Introduction to the Einleitung zur Grössenlehre, Bolzano adds a note, and then cancels it, on pure mathematics, which is defined as the science of quantities in abstracto, i.e. considered independently from the genus quantities belong to (geometrical quantities, mechanical quanties, and so on). Combining the new definition of quantity with the idea of a mathesis universalis, Bolzano applies mathematics to any kind of quantity, even abstract and non measurable quantities. In the same text he introduces the following definition:

I believe that the best thing to do would be to distinguish two meanings of the word 'quantity' [Grösse], a broader and a narrower meaning. In a narrower sense one could understand by quantity what one usually calls continuous quantities; in a broader sense one could take the word to include both the continuous and the so-called non continuous or discrete magnitudes, and nothing else. [...] It is in this broader sense, I think, that we call any object a quantity (quantum), when we consider it as belonging to a species of things, between any two of those we can assert one and just one of the following reciprocal relations: either they are equal one to the other or one contains a part that is equal to the other. ${ }^{53}$

\section{Conclusion: MATHEMAtics AS A MATHESIS UNIVERSAlis}

The analysis of Bolzano's changes in the definition of mathematics has shown that they are less radical than one might think. Several issues are common to the three works: 1) the definition of mathematics does not depend on its objects; 2) mathematics is exclusively conceptual; 3 ) its propositions are partly analytic and partly synthetic; 4) its objects are not just numbers, concrete continuous magnitudes, or magnitudes that can be measured. Notwithstanding those similarities, there are relevant issues that change in the three works: 1) mathematical objects are possible entities in 1810 but in 1837 and in 1848 they are conceived also as ideas in themselves, which cannot be possible, because they can never become actual; 2)

$52 \ddot{U b e r}$ den Begriff der Größe und die verschiedenen Arten derselben, §§ 11-12, in Bolzano [1977, p. 196]. This definition radically differs from the one presented in the manuscript on Mathesis universalis (1810), where measurability is still considered as an essential feature of quantities. Cf. Bolzano [1976] and the French translation by Maigné and Sebestik [2010].

${ }^{53}$ Grössenlehre, Einleitung, § 1, in Bolzano [1975, pp. 25-26]. 
mathematics is defined as a theory of forms in the Beyträge and as a science of quantities in the Grössenlehre; 3) mathematics is defined by opposition to philosophy and to other scientific disciplines in the Beyträge but not in the Grössenlehre; 4) in the Beyträge Bolzano remarks that analytic truths should not occur in a scientific treatment, given that they are only conventions used to recall the concept designated by a certain word, but in the Wissenschaftslehre analytic truths are considered as relevant enough to deserve a place in a scientific system, and sometimes even a proof; 5) Bolzano's anti-Kantianism evolves from 1810 to 1848.

Given the elements of continuity and the elements of discontinuity that we have described in the previous paragraphs, it is now possible to evaluate the coherence of Bolzano's evolution. Bolzano clearly renounced the aim that he had praised in 1810 - the idea of a sharp distinction between mathematics and other sciencesin favor of a more fluid and pragmatic classification of knowledge, but he always believed that mathematics cannot be adequately described by the indication of its domain of objects, and that mathematics does not concern only quantities, even if it is based on a quantitative approach to objects. Most differences concern minor points, or are perfectly understandable in the light of new definitions of the concepts involved. But what about the fundamental difference between forms that are possible and ideas or propositions in themselves that are not?

The difference is the result of Bolzano's continuous effort to defend the possibility of applying mathematical principles and theorems to the largest possible domain of objects. In the Grössenlehre Bolzano considers arithmetic and combinatorics as general sciences that can be applied to almost all kinds of things, and thus also to non actual objects. This is true of arithmetic, because numbers are not real objects, but just determinations of objects that can be used to determine all other quantities. ${ }^{54}$ And it is true of combinatorics, because the latter can be applied to any object that can be part of a whole. ${ }^{55}$ Bolzano's conception of mathematics as a general mathesis - first presented in 1810 - has not disappeared in the Grössenlehre. It is exactly for the sake of generality that Bolzano abandons the previous definition of mathematics and modifies the meaning of 'Grösse' from quantity to quantity in general, as it was common in the tradition of the mathesis universalis. ${ }^{56}$

\footnotetext{
54"Eine besondere Gattung von Grössen, welche sich unsrer Betrachtung vor andern darbieten, deren wir uns eben desshalb u. ihrer Einfachheit wegen zur genauern Bestimmung aller übrigen Grössen bedienen, sind - die Zahlen." Grössenlehre, Einleitung, § 3.5, in Bolzano [1975, p. 34]. 55“Denn sicher ist doch das Gebiet der Gegenstände, auf welche sich diese Gegenstände in irgend einem Betrachte als Theile vorstellte, die in ein eigenes Ganze vereinigt werden sollen, und dass diese Vereinigung einem Gesetze von der Art unterliege, dass es bei einer endlichen Menge von ihnen nur eine endliche Menge Verbindungen gibt." Grössenlehre, Einleitung, § 3.4, in Bolzano [1975, p. 36].

${ }^{56}$ On the characterization of quantities in the Grössenlehre see especially Sebestik [1992, p. 342].
} 
Bolzano's change in the definition of mathematics is thus a consequence of a deeper understanding of the meaning and the nature of the general mathesis. Bolzano's evolution is thus coherent. Rather than a change in his conception of mathematics, it is the result of a change in his logical and epistemological theory, and can be better understood in the light of an increased distance from the Kantian framework.

While Bolzano was still pervasively influenced by Kant in the Beyträge, so that Bolzano felt the need to present a definition of mathematics that should have the same advantages and characteristics of the Kantian definition, even if by opposition, his anti-Kantianism becomes much more radical as a consequence of the introduction of a new logical perspective. At this point, he does not need to produce a point by point counter-argumentation of Kant's theses: in particular, there is no more need for a definition of mathematics that might guarantee a sharp distinction between mathematics and other sciences, or explain the certainty of mathematics by opposition to philosophy. Bolzano's adhesion to the project of a mathesis universalis and his resistance to any bipartition of mathematics in theory of numbers and theory of magnitudes - numbers are themselves a kind of quantity - are coherent with his anti-Kantian conception of mathematics.

The idea of mathematics as being the science of quantities in general is the continuity element in Bolzano's evolution, which can be appreciated only if one develops a deep analysis of Bolzano's notion of quantity and of the changes it underwent with time. According to this interpretation, the conception of mathematics remains substantially unaltered, but Bolzano's investigation on the foundations of mathematics moves from a philosophical perspective that is still profoundly indebted to Kant's terminology and to Kant's definitional criteria towards a mathematical and algebraic conception which is much more concerned with a precise clarification of the primitive concepts of the discipline. It is exactly for this reason that Bolzano goes back to the traditional definition of mathematics: the linguistic use can be preserved, provided that one preliminarily clarifies the meaning of the concepts involved.

According to this interpretation, Bolzano's change in the definition of mathematics depends on a change in the logic (the introduction of ideas and propositions in themselves), which is, as I have shown elsewhere, ${ }^{57}$ strictly connected to the solution of certain mathematical needs (e.g. the need to explain how mathematics might contain meaningful propositions concerning objectless ideas). The belief in

\footnotetext{
${ }^{57}$ Cf. Cantù [2006] and Cantù [2003a]. Both papers are extracted from the dissertation Objectless ideas in the Wissenschaftslehre of B. Bolzano discussed in 2001 at the University of Genève (M.A. Philosophy and History of Logic) under the supervision of Kevin Mulligan, to whom I am deeply indebted for having introduced me to the study of Bolzano's works.
} 
the importance of logic for mathematics is probably the main reason for the radicalization of Bolzano's anti-Kantianism, and is coherently reflected in the evolution of his definition of mathematics. Bolzano's return to the traditional definition is the best compromise he could find in order to keep together the new logical theory with the idea of a mathesis universalis.

I have claimed in previous work that the need to legitimate the meaningfulness of certain contradictory ideas in mathematics was one of the reasons for Bolzano's developement of a theory of objectless ideas, which I interpreted by a comparison with Leibniz's notions of cogitatio possibilis and chimaera in the New Essays. Something similar can be claimed in the case of the definition of mathematics: the need to legitimate the use of imaginary quantities in mathematics was one of the reasons for Bolzano's return to an old definition which still expresses the conception of mathematics as a scientia universalis. A comparison with Leibniz is indirectly suggested by Bolzano himself in the Beyträge, even if the name of Leibniz is mentioned just once (or rather the Leibniz-Wolff school is mentioned), and in a slightly different context (in the second section of the Beyträge, $\S 1$, concerning the generality of the mathematical method which can be used in the presentation of any science), as Bolzano recalls the review of the book by Vieth, where Leibniz is praised for being, unlike Kant, mathematician and philosopher at the same time. ${ }^{58}$

To conclude, my general claim is that both the introduction of a new definition in the Beyträge and the return to the traditional definition of mathematics in the Grössenlehre can be interpreted as a change in terminology but not as a radical change in Bolzano's conception of mathematics. The change of definition is a coherent development of two fundamental ideas of Bolzano: 1) Kant's conception of mathematics is inadequate, and 2) mathematics is a scientia universalis. Changes are the result of the fact that Bolzano dinstanced himself more and more from Kant's perspective - because he developed a new logic as a result of certain urgent mathematical needs - and also from the traditional habit to define mathematics by opposition to other sciences, especially philosophy, as it was mostly the case in 18th century encyclopedias and dictionaries.

In other words, both definitions of mathematics (as a theory of forms and as a theory of quantities) are opposed to Kant's definition, and the second more than the first. Besides, as we will argue in the conclusion, both definitions arise from Bolzano's understanding of mathematics as a universal mathesis, but the second is based on a different notion of quantity $(\S 4)$. In both cases we will interpret the

\footnotetext{
58“Wir wissen es wohl, diese Definitionen rühren von einem berühmten Philosophen her; der aber zugleich hätte Mathematiker seyn müssen, wie Leibnitz, wenn er mit Erfolg die mathematischen Grundbegriffe hätte bestimmen sollen." Anonymous [1808, p. 1291].
} 
change as due to Bolzano's urgence to solve a specific mathematical problem: the question of contradictory concepts $(\S 5)$.

\section{REFERENCES}

Anonymous. von Spaun, Versuch das Studium der Mathematik durch Erläuterung einiger Grundbegriffe und durch zweckmässigere Methoden zu erleichtern. (Review). Jenaische Allgemeine Literatur-Zeitung, 251:177-182, 1807.

Anonymous. Vieth, Anfangsgründe der Mathematik (Review). Neue Leipziger Literaturzeitung, (81), July 1808.

Paola Basso. Il secolo geometrico. La questione del metodo matematico in filosofia da Spinoza a Kant. Le Lettere, Firenze, 2004.

Arianna Betti. Explanation in metaphysics and Bolzano's theory of ground and consequence. Logique et Analyse, 56(211):281-316, 2010.

Bernard Bolzano. Wissenschaftslehre. Versuch einer ausfürhlichen und grössentheils neuen Darstellung der Logik mit steter Rücksicht auf deren bisherigen Bearbeiter. Seidel, Sulzbach, 1837.

Bernard Bolzano. Beyträge zu einer begründeteren Darstellung der Mathematik. Wissenschaftliche Buchgesellschaft, Darmstadt, 1974. Erste Lieferung, Unveränderter reprografischer Nachdruck der Ausgabe von 1810, Mit einer Einleitung zum Neudruck von Hans Wussing.

Bernard Bolzano. Einleitung zur Grössenlehre und erste Begriffe der allgemeinen Grössenlehre. Bernard Bolzano-Gesamtausgabe. Bd. II.7: Nachlass. Nachgelassene Schriften. Frommann-Holzboog, 1975.

Bernard Bolzano. Mathematische und philosophische Schriften 1810-1816. Bernard Bolzano-Gesamtausgabe. Bd. II.7: Nachlass. Nachgelassene Schriften. Frommann-Holzboog, 1976.

Bernard Bolzano. Mathematische und philosophische Schriften 1810-1816. Bernard Bolzano-Gesamtausgabe: Nachlass. Frommann-Holzboog, 1977.

Bernard Bolzano. Miscellanea Mathematica 5. Bernard Bolzano-Gesamtausgabe. Bd. II.4/1: Nachlass. Wissenschaftliche Tagebücher. Frommann-Holzboog, Stuttgart, 1990.

Bernard Bolzano. Miscellanea Mathematica 15. Bernard BolzanoGesamtausgabeBd. II.9/1: Nachlass. Wissenschaftliche Tagebücher. FrommannHolzboog, Stuttgart, 2000.

Paola Cantù. Le rappresentazioni anoggettuali nella Wissenschaftslehre di Bernard Bolzano. Master's thesis, Université de Genève, Genève, June 2001.

Paola Cantù. Bernard Bolzano e le rappresentazioni anoggettuali. In Paolo Valore, editor, Forma dat esse rei, pages 125-166. Led, Milano, 2003a. 
Paola Cantù. La matematica da scienza delle grandezze a teoria delle forme. L'Ausdehnungslehre di H. Grassmann. PhD thesis, Università di Genova, Genova, January 2003b.

Paola Cantù. Bolzano et les propositions en soi: une théorie objective des vérités. In Jocelyn Benoist, editor, Propositions et états de choses. Vrin, Paris, 2006.

Paola Cantù. Mathematik als Größenlehre. In J. Stolzenberg and O.-P. Rudolph, editors, Christian Wolff und die europäische Aufklärung. Akten des 1. Internationalen Christian-Wolff-Kongresses, volume IV. Mathematik und Naturwissenschaften. Ästhetik und Poetik of Wolffiana II, pages 13-24, Hildesheim, 2008. Olms.

Paola Cantù. Bernard Bolzano. Contributi a una presentazione più fondata della matematica e altri scritti. Italian translation of Beyträge. forthcoming.

Willem R. de Jong. Kant's theory of geometrical reasoning and the analyticsynthetic distinction. On Hintikka's interpretation of Kant's philosophy of mathematics. Studies in History and Philosophy of Science, 28(1):141-166, 1997.

Guillaume Frechette. Gegenstandslose Vorstellungen: Bolzano und seine Kritiker. Academia, Sankt Augustin, 2010.

Jacob Klein. Die griechische Logistik und die Entstehung der Algebra. Quellen und Studien zur Geschichte der Mathematik, Astronomie und Physik. Abt. B. Studien, 3(1-2):18-105, 122-135, 1934-36.

Wolfgang Künne. Conceptions of Truth. Oxford University Press, Oxford, 2005.

Detlef Laugwitz. Bemerkungen zu Bolzanos Grössenlehre. Archive for History of Exact Sciences, 2:398-409, 1964/1965.

Carol Maigné and Jan Sebestik. Bernard Bolzano. Premiers Écrits. Philosophie, logique, mathématique. Vrin, 2010.

Edgar Morscher. Das logische An Sich bei Bernard Bolzano. Pustet, SalzburgMünchen, 1973.

Kevin Mulligan and Jean-Pierre Cometti, editors. La philosophie autrichienne de Bolzano à Musil, histoire et actualité. Vrin, Paris, 2001.

Franz Prihonsky. Neuer Anti-Kant und Atomenlehre des seligen Bolzano. Academia Verlag, Sankt Augustin, 2003.

Paul Rusnock. Philosophy of mathematics: Bolzano's responses to Kant and Lagrange. Rev. Histoire Sci., 52(3-4):399-427, 1999. Mathématique et logique chez Bolzano.

Paul Rusnock. Bolzano's Philosophy and the Emergence of Modern Mathematics, volume 30. Editions Rodopi B.V., Amsterdam, 2000.

Paul Rusnock and Mark Burke. Etchemendy and Bolzano on logical consequence. History and Philosophy of Logic, 31(1):3-29, 2010. 
Steve Russ. The Mathematical Works of Bernard Bolzano. Oxford University Press, Oxford, 2004.

Benjamin Schnieder. Mere possibilities. Bolzano's account of non-actual objects. Journal of the History of Philosophy, 45:525-50, 2007.

Jan Sebestik. Logique et mathématique chez Bernard Bolzano. Vrin, 1992.

Mark Siebel. Der Begriff der Ableitbarkeit bei Bolzano. Academia, Sankt Augustin, 1996.

Peter Simons. Philosophy and logic in Central Europe from Bolzano to Tarski. Kluwer, Dordrecht, 1992.

Hourya Benis Sinaceur. Bolzano et les mathématiques. In E. Barbin and M. Caveing, editors, Les philosophes et les mathématiques, pages 150-173. Ellipses, Paris, 1996.

Franz Anton Ritter von Spaun. Versuch, das Studium der Mathematik durch Erläuterung eniger Grundbegriffe und durch zweckmässigere Methoden zu erleichtern. Göbhardt, Mamberg und Würzburg, 1805.

Markus Textor. Bolzanos Propositionalismus. W. de Gruyter, Berlin; New York, 1996.

Gerhard Ulrich Anton Vieth. Anfangsgründe der Mathematik. Lehrbuch der angewandten Elementarmathematik. Barth, Leipzig, 1805.

CePerC, Université de Provence

E-mail address: paola.cantu@univ-provence.fr 